\title{
Some Changes in the Associative Dimension of the Concept
}

\author{
${ }^{1}$ Maia Chkheidze, ${ }^{2}$ Tina Gudushauri, ${ }^{3}$ Revaz Tabatadze \\ ${ }^{1}$ The University of Georgia, Georgia, ${ }^{2}$ The University of Georgia, Georgia \\ ${ }^{3}$ The University of Georgia, Georgia
}

\begin{abstract}
.
The present paper aims at identifying some changes in the associative dimension of the concepts of "family", Freedom" and "life".

The research of the associative dimension of the concepts is implemented by applying the method of the free associative experiment aimed at revealing informants' (English and Georgian speakers) associates-reactions to certain stimuli). The frequency ratios of reactions have been defined and the specifics of the core-periphery relationship has been identified in the associative fields.

The analysis of the material of the free associative experiment revealed that the concepts of "family", "freedom" and "life" perceived and interpreted by the respondents have been manifested in the cause-effect, temporal, and spatial relations.

The comparison of the lexical-semantic and associative fields has been made. The mentioned entities have been constructed by applying the principle of significance. According to the mentioned principle, each element of the field has been included in the system due to its meaning and significance determined on the basis of the system as a whole.
\end{abstract}

Keywords: Associative Dimension; Free Associative Experiment; Associative Field; LexicalSemantic Field; Extra Linguistic Realities.

\section{INTRODUCTION}

Our existence starts with the creation of the world view. We need some special symbolic structures (language, mythology, religion, arts, and science) to orientate in the universe. The mentioned structures regulate our existence in the universe; their unity creates the fundamental and global view that helps us to perform in the universe. Any major transformation causes changes in the regulation of human activities - ideals and principles of perception, activities, values and spiritual orientation. These regulators are variable in time and space. Being historically preconditioned, world view implies a constant change of the world view and its subjects. A world view gives impetus to values, hierarchy and thinking paradigms. From the 


\title{
8 International Conference on Research in
}

\section{BEHAVIORAL \& SOCIAL SCIENCES}

July $23-25,2021$

\author{
Stockholm, Sweden
}

perspective of the anthropocentric paradigm a man perceives the universe, in other words, a man creates anthropocentric centre in his consciousness which determines his spiritual essence, intentions of his actions and hierarchy of values.

The indispensable condition of human existence is the rationalization of the world. The process of rationalization of the world implies the process of thinking about the threats of the universe and developing the mechanisms to tackle them.

Each language possesses its own style of conceptualization. Accordingly, each language creates its own world view through which a speaker organizes the content of the expression (Corson, 1995).

Language is a means of forming human knowledge on the universe. The sum total of the knowledge, accumulated through linguistic forms, is the phenomenon called "lingual representation of the world".

How to think and talk about the impact the corona virus is having on our lives? How to deal with the epidemic explosion of new associations and neologisms? - The thing is that, these novelties help us make sense of our new world and reveal the specifics of the linguistic consciousness of man.

Let's see how the linguistic creativity manifests itself in times of serious crisis!

World War II gave us "radar" (radio detection and ranging), from Vietnam we got both "clusterfuck" (a mishandled or disorganised situation) and "fragging" (the deliberate killing of an unpopular member of one's own fighting unit, from the shortening of fragmentation grenade).

Lerer wrote, "War always changes language. It brings in new words, changes attitudes, [and] shifts dialects." (Lerer, 2007).

Wilfred Funk, author of "Word Origins and Their Romantic Stories," estimated that for each year the United States was involved in World War II, we added more than 6,000 words to the American vocabulary (Funk, 1950).

In 2011, author and slang expert Paul Dickson produced the third edition of his book "War Slang: American Fighting Words and Phrases Since the Civil War," in which he shows how language mirrors the unique experience of each conflict from the Civil War through the Iraq War (Dickson, 2003).

The scope of lexical innovation in relation to coronavirus is unprecedented - coronavirus neologisms are intensively being coined: "covidiot" (someone ignoring public health advice), "covideo party" (online parties via Zoom or Skype), and "covexit" (the strategy for exiting lockdown), "blursday" (an unspecified day because of lockdown's disorientating effect on time), to "zoombombing" (hijacking a Zoom videocall). "WFH" (working from home) and "quaranteams" (online teams created during lockdown), infodemic (information + epidemic).

The spread of information, some of it not so substantiated, contributing to anxiety or speculation, linked to a crisis or a controversy), coronabesity (corona + obesity), 


\title{
8 International Conference on Research in
}

\section{BEHAVIORAL \& SOCIAL SCIENCES}

July $23-25,2021$

\author{
Stockholm, Sweden
}

coronarelationship (a temporary relationship with somebody one knows maintained because one does not want to stay alone during the quarantine).

In 1950, prior to the Korean War, novelist Robert C. Ruark wrote in a syndicated newspaper column, "That seems to be one of the nicer things about war - it enriches the language so."

The same can be said about the corona virus: "That seems to be one of the nicer things about the corona virus - it enriches the language so."

\section{Methodology}

The research of the linguistic consciousness is implemented by applying the method of the free associative experiment aimed at revealing informants' (English and Georgian speakers) associates-reactions to certain stimuli (Deese, 1965). The experiment covered the informants of various specialties, the gender sign was in equal proportions.

Nearly 900 associative connections between the word-stimulus (life) and associates-reactions to it obtained through the free associative experiment have been analysed in the article. The frequency ratios of reactions have been defined and the specifics of the core-periphery relationship has been identified. The comparison of the lexical-semantic and associative fields of "life", "freedom" and "family" has been made.

The procedure of the free associative experiment revealed:

1. the similarities and differences between the linguistic world view depicted in the dictionaries;

2. the specifics of the perception of the concepts of "life", "freedom" and "family" by modern native speakers;

3. the character of the transformation of the linguistic world view according to the new extra linguistic realities.

Lexical-semantic fields of "life", "freedom" and "family" have been constructed by applying the componential analysis.

A word or lexeme represents a complex semantic structure made up of smaller components of meaning. In the complex structure of a lexeme the elements of meaning have definite interrelation. All semantic elements in a word are not equally important - one of them possesses the status of the dominant semantic element organizing around itself all the other ones, being more or less important for the meaning of a lexeme. The semantic structure of a lexeme is considered to be a system of meanings.

According to the semantic field theory, lexemes can be classified according to the shared and differential features. The semantic features explain how the members of the semantic domain are related to one another and how they can be used to differentiate them from one another. The determination of the shared and differential semantic features has been called componential analysis (Kreidler, 2002; Wardhaugh, 1977). 


\title{
BEHAVIORAL \& SOCIAL SCIENCES
}

\author{
July $23-25,2021$ \\ Stockholm, Sweden
}

According to Palmer, the total meaning of a word can be viewed as a number of distinct components of meaning (Palmer, 1983). The mentioned components have a differentiating function - they serve to distinguish the meaning of a lexeme from the semantically related lexemes, more precisely, they serve to differentiate the meanings of the lexemes in the same semantic domain.

Lexical-semantic fields of "life", "freedom" and "family" have been segmented by applying the principle of significance. According to the mentioned principle, each element of the field possesses meaning and significance simultaneously, in other words, each element of the field is included in the system due to its meaning and significance determined on the basis of the system as a whole (Lehrer \& Kittay, 1992).

So, we constructed the lexical-semantic fields of "life", "freedom" and "family" considering that:

1. The meaning should be derived from the regularity of the entire structure;

2. Each element, being the member of the value system, should be determined by other elements, in other words, the system should determine its elements;

3. The field should be regulated by the law of organic separation;

4. The members of the organic entity should affect each other.

To conduct the research the descriptive method to characterize the phenomena of language at this stage of its development has been used. The comparative method helped to determine general and specific features of the English and the Georgian languages. The statistical method has been applied to reveal the most frequent associates existing in the linguistic consciousness of native speakers. The experimental method, in particular, the method of the free associative experiment has been considered to be an effective method to study the linguistic consciousness. In the free associative experiment, the stimuli "life", "freedom" and "family" called up a number of unique and universal associations of the language speakers. On the basis of the reactions of native speakers to the stimuli "life", "freedom" and "family" the associative fields of "life", "freedom" and "family" have been modelled. To construct the lexical-semantic fields of "life", "freedom" and "family" the componential analysis of the semantic structure of the field elements has been conducted.

\section{RESULTS AND DISCUSSION}

The analysis of the lexicographic definitions of "life" revealed four lexical-semantic variants:

1. A state of organisms characterized by the capacity to perform certain functional activities, including, breath, growth, reproduction, metabolism, reaction to stimuli, that makes people, animals, and plants different from objects, substances, and things that are dead;

2. The interval of time between somebody's birth and their death; or the period for which a machine or organization lasts; 


\section{$8^{\text {th }}$ International Conference on Research in \\ BEHAVIORAL \& SOCIAL SCIENCES}

July 23-25,2021 Stockholm, Sweden

3. The events and experiences that happen to people while they are alive; the things that people do and experience that are characteristic of a particular time, place, or group of people;

4. A book which tells the story of someone's life, written by someone else or by that particular person, i.e. biography/autobiography.

Figure 1: I lexical-semantic variant and its elements

\begin{tabular}{|l|l|}
\hline \multicolumn{2}{|c|}{ I lexical-semantic variant } \\
\hline Elements & $\begin{array}{l}\text { blood; body; animal; man; being; person; activity; } \\
\text { existence; creature; growth; impulse; viability; } \\
\text { organism; mortal; flesh; vitality; breath; wild; woman; } \\
\text { consciousness; symbiosis; subsistence; human; } \\
\text { metabolism. }\end{array}$ \\
\hline
\end{tabular}

Figure 2: II lexical-semantic variant and its elements

\begin{tabular}{|l|l|}
\hline \multicolumn{2}{|c|}{ II lexical-semantic variant } \\
\hline Elements & man; person; feel; woman; heart; body; being; animal; \\
& real; human; breath; warm; skin; blood; human being; \\
& presence; alive; physical; flesh; mental; \\
& $\begin{array}{l}\text { consciousness; natural; activity; energy; unconscious; } \\
\text { creature; existence; survival; growth; function; alert; } \\
\text { dynamic; vitality; organ; mortality. }\end{array}$ \\
\hline
\end{tabular}

Figure 3: III lexical-semantic variant and its elements

\begin{tabular}{|l|l|}
\hline \multicolumn{2}{|c|}{ III lexical-semantic variant } \\
\hline Elements & $\begin{array}{l}\text { way of life; world; activity; conduct; career; } \\
\text { personality; behaviour; experience; situation; } \\
\text { lifestyle; culture; civilization; society. }\end{array}$ \\
\hline
\end{tabular}

Figure 4: IV lexical-semantic variant and its elements

\begin{tabular}{|l|l|}
\hline \multicolumn{2}{|c|}{ IV lexical-semantic variant } \\
\hline Elements & $\begin{array}{l}\text { history; life story; confession; diary; bio; profile; } \\
\text { journal. }\end{array}$ \\
\hline
\end{tabular}

Figure 5: Associative field of "Life"

\begin{tabular}{|l|l|}
\hline \multicolumn{2}{|c|}{ Associative field of "Life" } \\
\hline Associates & Covid-19; fear; danger; epidemic; lockdown; death; \\
& dead; end; fatality; loss of life; departure from life; \\
& collapse; blursday; WFH; quaranteams; covideo \\
& party; zoombombing; man; person; feel; woman; \\
& heart; body; being; animal; real; human; breath; \\
& warm; skin; blood; human being; presence; alive; \\
& physical; flesh; mental; consciousness; natural; \\
& activity; energy; unconscious; creature; existence; \\
& survival; growth; function; alert; dynamic; vitality;
\end{tabular}




\title{
$8^{\text {th }}$ International Conference on Research in
}

\section{BEHAVIORAL \& SOCIAL SCIENCES}

\author{
July $23-25,2021$ \\ Stockholm, Sweden
}

\begin{tabular}{|l|l|}
\hline & $\begin{array}{l}\text { organ; mortality; time; hour; pass; day; course; age; } \\
\text { moment; start; spend; go on; future; stage; period; } \\
\text { daily; existence; episode; lifetime; duration; lifelong; } \\
\text { perpetual; continuance; span; endurance; work; } \\
\text { world; full; relationship; empty; marriage; experience; } \\
\text { event; college; situation; ordinary; private; plan; } \\
\text { career; activity; torture; culture; society; behaviour; } \\
\text { lonely; domestic; location; development; social life; } \\
\text { comfort zone; conduct; personality; story; history; } \\
\text { write; character; film; describe; life story; confession; } \\
\text { diary; novel; drama; page; photo album; biography; } \\
\text { autobiography... }\end{array}$ \\
\hline
\end{tabular}

The analysis of the lexicographic definitions of "Freedom" revealed the following lexicalsemantic variants:

1. The state of being free from the control or power of another;

2. The right to act or move freely.

Figure 6: Synonyms of the first lexical-semantic variant

\begin{tabular}{|l|l|}
\hline \multicolumn{2}{|c|}{ I lexical-semantic variant } \\
\hline Elements & $\begin{array}{l}\text { autonomy; independence; independency; liberty; self- } \\
\text { determination; self-governance; self-government; } \\
\text { sovereignty. }\end{array}$ \\
\hline
\end{tabular}

Figure 7: Words related to "freedom"

I lexical-semantic variant

\begin{tabular}{|l|l|}
\hline Elements & $\begin{array}{l}\text { Emancipation; enfranchisement; liberation; } \\
\text { manumission; release... }\end{array}$
\end{tabular}

Figure 8: Synonyms of the second lexical-semantic variant

\begin{tabular}{|l|l|}
\hline \multicolumn{2}{|c|}{ II lexical-semantic variant } \\
\hline Elements & authorization; free hand; latitude; license; run. \\
\hline
\end{tabular}

Figure 9: Words related to "freedom"

\begin{tabular}{|l|l|}
\hline \multicolumn{2}{|c|}{ II lexical-semantic variant } \\
\hline Elements & $\begin{array}{l}\text { authority; clutch; command; control; dominion; grip; } \\
\text { hold; mandate; mastery; power; sway; range; room; } \\
\text { space; blank check; carte blanche... }\end{array}$ \\
\hline
\end{tabular}

Figure 10: Associative field of "Freedom"

\begin{tabular}{|l|l|}
\hline \multicolumn{2}{|c|}{ Associative field of "Freedom" } \\
\hline Associates & $\begin{array}{l}\text { lockdown; Covid-19; fear; danger; death; loss of life; } \\
\text { loss of freedom; blursday; censorship; equality; }\end{array}$ \\
\hline
\end{tabular}




\section{$8^{\text {th }}$ International Conference on Research in}

BEHAVIORAL \& SOCIAL SCIENCES

July 23-25,2021 Stockholm, Sweden

\begin{tabular}{|l|l|}
\hline & independence; democracy; fighter; tyranny; liberty; \\
speech; rights; emancipation; slavery; conscience; \\
oppression; autonomy; liberalism; restriction; \\
libertarian; amnesty; expression; slave; individuality; \\
constitution; openness; religion; infringement; \\
struggle; violation; dignity; tolerance; fascist; \\
rationality; discrimination; dictatorship; prosperity; \\
authoritarian; constitutional; unconstitutional; \\
journalistic; slave; intolerance; patriotism; enjoyment; \\
fairness; morality; creativity; humanism; anarchy; \\
enlightenment; press; transparency; terrorism; \\
idealism; citizen; feminism; neutrality; free; exercise; \\
accord; symbolize; tranquillity; protection; \\
intellectual; absolute; justice; revolutionary; \\
immortality; regime; slogan; belief; legislation; \\
happiness; responsibility; populist; conservatism; \\
brotherhood; peace; dogma; taxation; respect; \\
imprisonment; political; unlimited; courageous...
\end{tabular}

The analysis of the lexicographic definitions of "family" revealed the following lexicalsemantic variants:

1. A group of persons who come from the same ancestor;

2. One of the units into which a whole is divided on the basis of a common characteristic .

Figure 11: Synonyms of the first lexical-semantic variant

\begin{tabular}{|l|l|}
\hline \multicolumn{2}{|c|}{ I lexical-semantic variant } \\
\hline Elements & $\begin{array}{l}\text { blood; clan; folks; house; kin; kindred; kinfolk; } \\
\text { kinsfolk; line; lineage; people; race; tribe. }\end{array}$ \\
\hline
\end{tabular}

Figure 12: Words related to "Family"

\begin{tabular}{|l|l|}
\hline \multicolumn{2}{|c|}{ I lexical-semantic variant } \\
\hline Elements & $\begin{array}{l}\text { blended family; nuclear family; extended family; } \\
\text { household; descendant; offspring; clansman; } \\
\text { kinsman; kinswoman; relative; dynasty... }\end{array}$ \\
\hline
\end{tabular}

Figure 13: Synonyms of the second lexical-semantic variant

\begin{tabular}{|l|l|}
\hline \multicolumn{2}{|c|}{ II lexical-semantic variant } \\
\hline Elements & $\begin{array}{l}\text { category; class; classification; division; genus; group; } \\
\text { kind; league; order; rank(s); set; species; type. }\end{array}$ \\
\hline
\end{tabular}

Figure 14: Words related to "Family"

\begin{tabular}{|l|l|}
\hline \multicolumn{2}{|c|}{ II lexical-semantic variant } \\
\hline Elements & $\begin{array}{l}\text { sort; subclass; subdivision; subgroup; subspecies; } \\
\text { variety; breed; race; generation... }\end{array}$ \\
\hline
\end{tabular}


July 23-25,2021 Stockholm, Sweden

Figure 15: Associative field of "Family"

\begin{tabular}{|c|c|}
\hline \multicolumn{2}{|c|}{ Associative field of "Family" } \\
\hline Associates & $\begin{array}{l}\text { cluster; quaranteams; Covid-19; fear; danger; } \\
\text { epidemic; lockdown; death; household; poverty; } \\
\text { genus; income; couple; husband; species; parenting; } \\
\text { genealogy; belonging; descendant; kinship; relative; } \\
\text { sibling; grandparent; population; mafia; age; spouse; } \\
\text { ancestor; aristocratic; size; wealthy; average; female; } \\
\text { adoptive; married; genealogical; noble; living; } \\
\text { patriarchal; ancestral; royal; hereditary; paternal; } \\
\text { reside; immigrate; emigrate; inherit; born; clan; child; } \\
\text { vacation; grandfather; grandmother; together; } \\
\text { orphaned; male; dynastic; marital; maternal; } \\
\text { prosperous; descend... }\end{array}$ \\
\hline
\end{tabular}

The analysis of the associative fields of "life", "freedom" and "family" constructed by us in March 2021 revealed that the mentioned fields share the following elements: Covid-19; fear; danger; death; lockdown.

The continua of the associative fields of "life", "freedom" and "family" are variable in time new realities have shaped and transformed their continua. We interpret the transformation occurring in the continua of the associative fields of "life" "freedom" and "family" as the result of the continuous (permanent) reproduction (interpretation and reinterpretation) of the reality.

The difference between the psychological "content" of a word and the meaning of the word presented in the dictionary definition is obvious. The dictionary definition of a word does not and cannot take into account some shift in the meaning of a word.

The associative field is always more voluminous than the lexical-semantic field. The associative field comprises all the reactions-associates allowing identification of the essential markers of the native speakers' world view.

The associative field reveals the specifics of a respondent's relation to a word-stimulus, while the semantic field describes the relation of a given word to other words.

Free associative experiment presents the current psychological significance of a word for native speakers, reveals some similarities and differences between the real semantics of a word and the meaning of the word presented in the dictionary definition.

Free associative experiment determines the associative "range" of a word and presents it as its psychological "content".

The analysis of the material of the free associative experiment revealed that the concept of "life", "freedom" and "family" perceived and interpreted by the respondents has been manifested in the cause-effect, temporal and spatial relations. 


\section{$8^{\text {th }}$ International Conference on Research in \\ BEHAVIORAL \& SOCIAL SCIENCES}

July $23-25,2021$

Stockholm, Sweden

\section{Conclusion}

The essential part of the associative and lexical-semantic fields of "life", "freedom" and "family" in English and Georgian is focused on the sphere of linguistic consciousness and cognitive perception.

The research of linguistic consciousness implemented by the method of the free associative experiment identified the similarities and differences between the linguistic worldview depicted in the dictionaries, revealed the specifics of the perception of the concepts of "life", "freedom" and "family" by native speakers and determined the character of the transformation of the linguistic worldview according to the new extra linguistic realities.

Novelties are triggered by social and political events especially in times of war and natural disasters. However, the case for the corona virus is different, since associations and neologisms generated by the corona virus are of global meaning.

Neologisms are coined and associations are created to fill a void created by perception, demonstrating the influence of perception over language. In turn, neologisms and associations influence the perception of language speakers.

The analysis of the reactions to the stimuli "life", "freedom" and "family" showed that novelties have created new associative dimensions of the concepts. The associative fields of "life", "freedom" and "family" constructed in the English and Georgian languages coincide in general.

\section{References}

Corson, D. (1995). Worldview, Cultural Values and Discourse Norms: The Cycle of Cultural Reproduction.” International Journal of Intercultural Relations 19.

Deese, J. (1965). The structure of associations in language and thought. Baltimore: Johns Hopkins Press.

Dickson, P. (2003). War Slang: American Fighting Words \& Phrases Since the Civil War. Brassey's, Inc.

Funk, W. (1950). Word origins and their romantic stories. New York: Funk \& Wagnalls.

Kreidler, Ch. (2002). Introducing English Semantics; New York, Routledge.

Lehrer, A., Kittay, E. F. (1992). Frames, Fields, and Contrasts. Hillsdale, NJ: Erlbaum. 
$8^{\text {th }}$ International Conference on Research in

\section{BEHAVIORAL \& SOCIAL SCIENCES}

July 23-25,2021 Stockholm, Sweden

Lerer, S. (2007). Inventing English: A Portable History of the Language. Columbia University Press: New-York.

Palmer, F. R. (1983). Semantics; Cambridge: Cambridge University Press.

Wardhaugh, R. (1977). Introduction to Linguistics; United States: McGraw-Hill. 